\title{
NORTHERN RECORD: LARK BUNTING NESTING COLONY NEAR SASKATOON, 1966
}

\author{
by Robert R. Cohen, and Maureen Rever, U. of S., Saskatoon
}

The A.O.U. Check-list of North American Birds (1957) gives the following northern breeding boundary for the Lark Bunting (Calamospiza melanocorys): southern Alberta (Waterton Lakes Park, Castor), southern Saskatchewan (Skull Creek, Indian Head), and southeastern Manitoba (Brandon). However, many sight records of this species have been made to the north of this boundary. Sightings were particularly common during 1965 and 1966, which strongly suggest a definite northward extension of the species' breeding range in Saskatchewan. In June of 1966 a large breeding colony of the species was located near Clavet (14 mi. S.E. of Saskatoon); this appears to be a northern breeding record for the species.

Records of Lark Buntings seen during the breeding season have been reported rather sporadically from several northern Saskatchewan and Alberta locations. One individual was seen near Prince Albert in 1909 (Ferry, 1910), and another near Carlton in 1939 (Houston and Street, 1959). Street (Houston and Street, 1959) regards the species as a rare straggler in the Nipawin area; a male was seen near Nipawin by Street in 1946 and another at Torch River in 1950 by C. Stuart Francis (Francis, $1950)$. Kvinge saw approximately 10 pair near Hawarden, in 1960, and in the same year the first sight records were made by J. B. Gollop and R. Folker in the Saskatoon area (Roy, 1960). The March 1965 Blue Jay (page 27) reported that Anweiler and Carson saw a male near Tisdale in 1964, and individuals have been seen near Dewberry, Alta. (60 mi. N.W. of Lloydminster) and at Kinloch (22 mi. N.E. of Kelvington). Roy (1964) states that the species was common in the Elbow area of the South Saskatchewan River (50 to $100 \mathrm{mi}$. S. of Saskatoon) from 1935 to 1946 and again in the last several years.
Included in the files of the Prairie Nest Record Scheme of the Saskatchewan Natural History Society are several nest records from the Regina and Moose Jaw area from recent years. Nest records are also included from Kyle, Sask. (by R. Fyfe in 1959), North Portal (by R. Lein in 1960), Skull Creek (by S. Mann in 1961, 1963), and Masefield (by D. Chandler, 1963).

A distinct influx of Lark Buntings in the region south of Saskatoon was noted in 1965: Fifty-six birds were seen in the area of Goose Lake, near Delisle (Gollop et al, 1965), and Slimmon (pers. comm.) reports that two nests were found in a colony of five or six pairs near this area, at Swanson (approximately $40 \mathrm{mi}$. S.W. of Saskatoon).

Near the first of June, 1966, several Lark Buntings were sighted in the Saskatoon area (Gollop, 1966). The breeding colony near Clavet was located shortly thereafter. On June 15 we led a group of University students to the area and located a nest with three eggs. At that time the breeding colony appeared to extend over an area approximately $1 \frac{1}{2} \mathrm{mi}$. by $1 \frac{1}{2} \mathrm{mi}$. lying on both sides of Highway 14 to the west of Clavet. The area consisted mainly of summer-fallow fields, with scattered patches of grassy prairie, brome-alfalfa hay meadow, and groves of snowberry, rose, and aspen. We estimated that at that time approximately 175 males were present in this area.

Singing males appeared to be most abundant in the northeast corner of the above-described area, and this is where the first nest was located. We returned to this location on June 18 with drag-ropes and found 7 additional nests. Numbers of eggs were 3 (plus 2 eggs of the Brown-headed Cowbird, Molothrus ater), 5, 5, 4, 3, and 5. On this date the previouslylocated nest contained 6 eggs. A ninth 
nest, with 2 eggs, was found in the area on June 24, and at that time the first nest contained 4 young. A tenth nest was found on July 2, with 4 young. On that date the young of one nest were banded by J. Slimmon.

According to the relative size of the area covered in searching for nests, the number of nests found, and the number of singing males within this area, we estimated that at least 100 nests existed in the entire colony.

The area in which most nests were found had been plowed by Mr. Rudy Daniels, owner of the eastern portion of the colony area, during the first week in June, after it had developed a moderate growth of Flixweed (Descurainia sophia). Substantial rains followed the date of plowing, so that by June 15 growth of this plant was again abundant. However, the overall appearance was that of bare turned soil with rows and hummocks of dead shoots. Most nests were located in depressions on the north side of such hummocks, and were constructed of grass. The nests and their locations therefore corresponded closely to the description by Pearson et al (1917) as typical for this species.

Whatever nesting success the birds had was partly due to the friendly cooperation of $\mathrm{Mr}$. Daniels, who was quite interested in the birds and in our survey. (According to him, the species had not been common in this area in previous recent years.) $\mathrm{He}$ offered to refrain from plowing the located nest areas until nesting was completed. Neverthless, other factors appeared to take their toll of birds. A number of nests were found to be vacant on June 24 and the density of adults appeared to be reduced. A large part of this destruction may have been due to the heavy rains during the third week of June. In addition, many of the birds were probably taken by Swainson's Hawks (Buteo swainsoni) which we saw on a few occasions in the area. Mr. Daniels stated that the hawks had nested on the area in recent years and probably did so again this year.

By July 16 all nests were vacant.

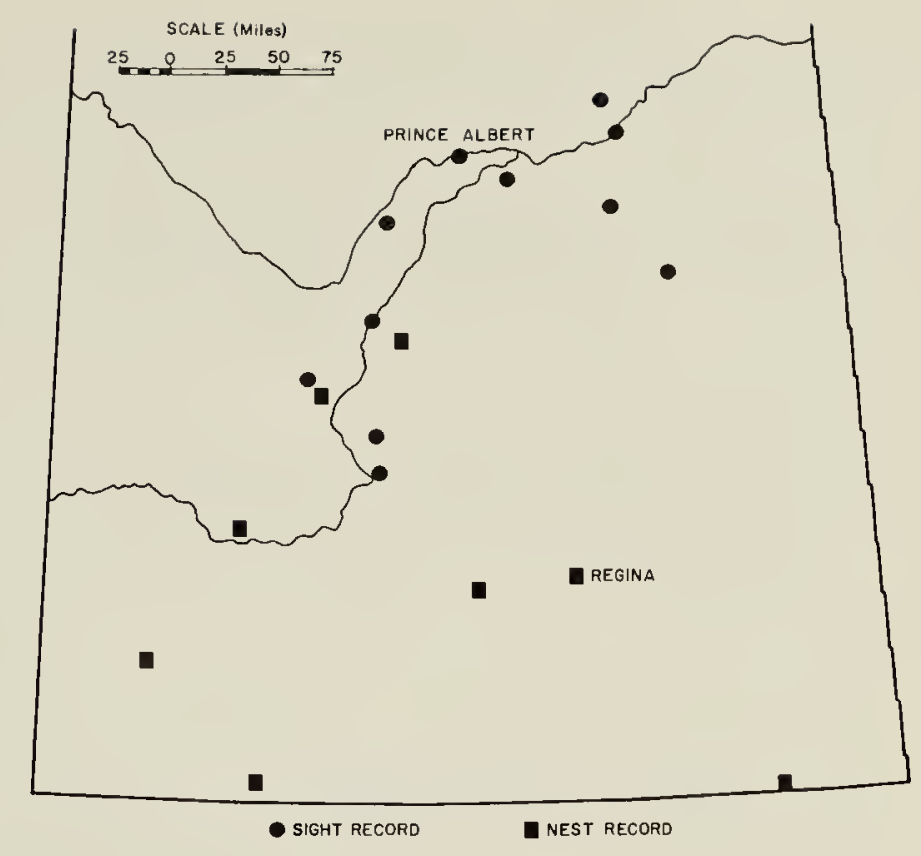

On July 20 the birds, including a substantial number of fully-fledged juveniles, were still common on the area, and several specimens were collected for the Department of Biology Museum by R. Lein and ourselves.

Nests of three other species were found during our surveys of the colony: five nests of Horned Lark (Eremophila alpestris), two of Western Meadowlark (Sturnella neglecta), and one of Wilson's Phalarope (Steganopus tricolor). Two of the Horned Lark nests contained cowbird eggs when they were found on June 18 . Two other species common in the colony area were the Clay-colored Sparrow (Spizella pallida) and the Vesper Sparrow (Pooecetes gramineus).

The University personnel who worked on this project with us were P. Bhattacharya, D. Derby, W. Fysh, S. Gibney, W. Hamilton, N. Hellman, G. Michalenko, M. Swift, B. Wright, and S. Van Vliet.

In summary, a large breeding colony of the Lark Bunting was located in June of 1966 just west of Clavet, Sask. Ten nests were found, and it is estimated that at least 100 nests existed in the entire colony. This appears to be a northern nesting record for this species. The relative abundance of the species in the last two years in areas within 50 miles of Saskatoon suggests that a northward extension of their breeding range may be taking place. 


\section{LITERATURE CITED}

American Ornithologists' Union. 1957. Checklist of North American birds. 5th Edition. p. 585 .

Ferry, J. F. 1910. Birds observed in Saskatchewan during the summer of 1909. Auk 27: 185-204. Cited by Houston and Street (1959).

Francis, C. S. 1950. Lark Bunting. Blue Jay $8(3): 9$.

Gollop, J. B. 1966. Saskatoon Bird Review $1(3): 23$.

Gollop, J. B., J. A. Slimmon, and R. V. Folker, 1966. Some 1965 bird records for the Saskatoon district. Blue Jay 24 :76-78.
Houston, C. S. and M. G. Street. 1959. The birds of the Saskatchewan River. Saskatche. wan Natural History Society. p. 186.

Kvinge, H. 1960. Influx of Lark Buntings at Hawarden. Blue Jay $18: 118$.

Pearson, T. G. et al, editors. 1917. Birds of America. Garden City Publ. Co.: New York. Part III, p. 76 .

Roy, J. F. 1960. Birds of special interest in the Saskatoon area, spring, 1960. Blue Jay $18: 117-118$.

Roy, J. F. 1964. Birds of the Elbow. Saskatchewan Natural History Society. p. 30 .

\title{
RECENT OBSERVATIONS OF THE FIELD SPARROW IN MANITOBA
}

\author{
by Martin McNicholl, 1281 Valour Road, Winnipeg
}

In the early afternoon of October 3, 1965, when I was carrying out a routine check of the birds in Brookside Cemetery, Winnipeg, I was surprised to hear a bird in song. I could not recall ever having heard the song before, but believed it to be one of the small sparrows. Anxious to identify the author of a bird-song in October, I immediately headed towards the sound. My suspicions of a small sparrow were further strengthened on finding that the song came from an area of the cemetery where native prairie with tall grasses still remains almost untouched except for a fairly large brush pile and a few small trees. This is a favorite spot of migrant sparrows.

On spotting the singer, I at first thought it was a Tree Sparrow (Spizella arborea). Suddenly, however, I realized that the bird had a distinctly pink bill. Suspecting a Field Sparrow (Spizella pusilla), I noted the following features through $8 \times 42$ binoculars: "pink bill, clear greyish breast with no breast spot, whitish wing bars, greyish-brown nape, reddish in wings and upper regions (and cap), and whitish throat." The lack of a breast spot was not entirely convincing, as I have seen Tree Sparrows in the fall without this very characteristic feature.
Moreover, I could not be positive that the bird had a white eye-ring, although I thought it did. Suddenly, however, the bird moved closer to me, erabling me to make out the eye-ring clearly. I was then convinced that I was watching a Field Sparrow. My conclusion was verified later in the afternoon by Mr. Vere Scott.

This observation again opened the question of the status of the Field Sparrow in Manitoba. E. E. Thompson (=Ernest Thompson Seton) never recorded it personally, but in his Birds of Manitoba (1890) he recorded the following statements: "Very rare summer resident. Red River Settlement: Breeding (D. Gunn) Winnipeg: Summer resident; tolerably common (Hine). Have seen it west of Winnipeg (R. H. Hunter). Qu'Appelle: common summer resident; breeds; arrives April 15 (Guernsey)."

The above observations were believed by John Macoun (Macoun and Macoun, 1909) to be mostly, if not completely, in error; Macoun was convinced that these observers were probably referring to the Clay-colored Sparrow (Spizella pallida),.. which, although abundant in southern Manitoba, was not mentioned by Guernsey, Hunter or Hine.

The Field Sparrow was not definitely recorded in Manitoba until 